\title{
Characteristics of Tip of the Tongue Phenomenon on the Task of Naming Celebrities in Healthy Elderly
} Adults

\author{
Soojung Kim ${ }^{\mathrm{a}}$, Hyunjoo Choi ${ }^{\mathrm{b}}$ \\ ${ }^{a}$ Highcog Brain Learning Center, Yangju, Korea \\ ${ }^{b}$ Department of Communication Disorders, Korea Nazarene University, Cheonan, Korea
}

Correspondence: Hyunjoo Choi, $\mathrm{PhD}$ Department of Speech-Language Pathology, Korea Nazarene University, 48 Wolbong-ro, Seobuk-gu, Cheonan 31172, Korea

Tel: $+82-41-570-1677$

Fax: +82-41-570-7849

E-mail: hjchoi@kornu.ac.kr

Received: October 4, 2021

Revised: October 27, 2021

Accepted: November 3, 2021

This work was supported by the Ministry of Education of the Republic of Korea and the National Research Foundation of Korea (NRF2019S1A5A2A01035719).
Objectives: In general, the incidence of Tip of the tongue (TOT) phenomenon increases with age, but studies on the difference in the incidence of TOT phenomenon according to the age of healthy elderly adults are limited. The purpose of this study was to investigate the incidence and resolution rate of the TOT, and to find out the change in performance according to the syllabic clues. Methods: Ninety-six healthy elderly people whose age range was between 65 and 84 years old participated in the study. Participants were divided into three groups: 55-64 years old, 65-74 years old, and 75-84 years old age range groups. The TOT task used 30 questions about celebrity naming organized by period and category. Results: First, there was a significant difference of the TOT rate by age group, and as the age increased, the TOT rate due to partial retrieval failure and total retrieval failure increased. Second, the rate of TOT response type that explained the celebrity's occupation was the highest in all groups. Third, there were significant differences between groups in both the voluntary TOT resolution rate and the TOT resolution rate after providing the syllabic clue. The recovery rate after the syllabic clues decreased with increasing age. Conclusion: This study observed the difference in characteristics of TOT phenomenon in elderly adults according to age group and the importance of phonological clues in TOT phenomenon resolution.

Keywords: Aging, Task of naming celebrities, Tip of the tongue phenomenon, Syllabic clue
의학의 발달과 전반적 생활수준의 향상으로 인간의 수명은 점 차 늘어나고 노인 인구의 비율도 빠르게 증가하고 있다. 통계청에서 발표한 2019 고령자 통계(Statistics Korea, 2019)에 따르면, 우리나 라에서 65세 이상 고령자가 전체 인구에서 차지하는 비율은 2019 년에 $14.9 \%$ 였으며, 2025년에는 $20.3 \%, 2067$ 년에는 $46.5 \%$ 에 달할 것으로 예상된다. 노인 인구의 증가에 따라 노화와 관련된 인지 능 력 변화에 대한 관심 또한 증가하고 있다(Kim, Hwang, Kim, \& $\mathrm{Kim}, 2013)$. 이러한 노화로 인한 인지 및 언어 능력의 변화는 치매 나 실어증과 같은 신경 손상 환자에게서 나타나는 것과는 구별되 기 때문에(Park, Shin, \& Son, 2012), 일반 노인의 인지, 언어 능력과 관련된 연구결과는 신경언어장애 환자를 감별진단하는 데 있어서 중요한 규준 정보로 활용될 수 있다(Kim et al., 2013). 지금까지 일
반 노인의 언어 및 의사소통과 관련된 연구는 지속적으로 이루어 져 왔으며, 그중 언어 산출 능력을 평가하기 위한 다양한 과제들이 사용되어 왔다(LaBarge, Edwards, \& Knesevich, 1986; Ulatowska, Chapman, Highley, \& Prince, 1998; Zec, Markwell, Burkett, \& Larsen, 2005). 특히, 이름대기와 관련된 연구는 가장 활발히 이루 어져 왔는데, 대체로 고령자에게는 이름대기 능력의 손상이 나타 나며 이로 인해 일상생활의 곤란을 겪는 것으로 알려져 있다(Kim $\& \mathrm{Kim}, 2009)$. 이러한 고령자의 이름대기 능력 저하는 인지적 느림, 비효율적 인지처리 과정과 같은 노화로 인한 신경학적 변화와 관련 이 높은 것으로 알려져 있다(Tsang \& Lee, 2003). 일반적으로 시각 자극을 통한 이름대기는 대상인식을 위한 시각 정보 활용 능력, 의 미기억(semantic memory)을 통한 정보의 활성화, 어휘-음운(lexi- 
cal-phonological) 처리 과정이 요구된다(Bowles, 1993).

이름대기 과정에서 해당 단어를 분명히 알고 있다고 느끼고 의미 정보는 떠올릴 수 있으나 이름을 생각해낼 수 없는 현상이 나타나기 도 하는데, 이를 '설단현상(Tip of the Tongue phenomenon, TOT)' 이라 한다(Brown \& McNeill, 1966). 설단현상을 설명하는 주요 가 설로는 불완전 활성화 가설(incomplete activation hypothesis)과 전달 결함 가설(transmission deficit hypothesis)을 들 수 있다. 불완 전 활성화란 의미기억을 통해 목표단어를 떠올릴 때 기억이 난다고 여기지만 완전한 회상(recall)을 유도할 만큼은 아닌 불완전한 기억 의 상태를 의미한다(Brown \& McNeill, 1966). 이 가설에 따르면 활 성화 정도에 따라 목표단어 전체를 떠올리는 데 실패할 수도 있고, 목표단어의 일부만을 떠올리지 못해 부분 회상이 가능한 경우도 있게 된다. 또한, 설단현상을 경험하는 상황에서 불활성화된 기억 의 강도가 증가하거나 변화하여 설단현상을 해결하게 되는 경우도 있다(Schwartz, 1999). 이러한 관점에서 노인들은 노화로 인해 청년 층에 비해 목표단어의 회상 능력이 제한되고, 기억의 활성화 수준 이 저하되어 설단현상이 더 빈번히 나타나게 된다. 또한, 인지적 느 림, 비효율적 인지처리 과정으로 인해 설단현상을 해결하는 능력 또한 제한된다. 다음으로 전달 손실 가설은 어휘가 불완전하게 활 성화되었을 때 의미 단계(semantic level)에 대한 접근은 어느 정도 가능하지만, 일부 음운 단계(phonological level)의 전달이 불충분하 여 설단현상이 나타난다고 설명하고 있다(Burke, MacKay, Worthley, \& Wade, 1991; Ecke \& Garrett, 1998). 즉, 설단현상은 의미기억 장소에서 음운기억 장소로 활성화하는 과정에서 발생하며(Schwartz, 1999), 음운 인출 실패와 관련이 있다. 의미적 활성화에 비해 음운 인출에 어려움이 가중되는 이유는 이 둘의 명제 마디의 차이 로 설명할 수 있다. 즉, 이름대기 과정 중 의미체계에서는 한 어휘에 여러 개의 명제 마디가 연결되어 있어 그 중 하나가 활성화되지 않 더라도 다른 마디가 활성화되어 보상이 가능하나, 음운체계에서는 명제 마디들이 위계적으로 단일하게 연결되어 있어 점화 전달 결함 으로 특정한 음운 마디가 활성화되지 못하면 해당 음운 인출에 실 패하게 되고, 다른 마디의 활성화로 보상할 수가 없다(Park, Lee, \& Lee, 2013). 이와 관련하여 노인들은 청년에 비해 목표단어의 철자를 잘못 보고하거나 잘 아는 단어의 철자를 떠올리지 못하는 경우가 더 빈번하다고 알려져 있는데(Lee \& Lee, 2011; MacKay \& Abrams, 1998), 이는 노인들이 음운 정보 산출에 어려움을 보인다는 것을 설 명하는 현상이다(Park et al., 2013; Ryan, See, Meneer, \& Trovato, 1992). 이렇듯 설단현상은 일반적으로 노인에게 많이 나타나며 (Resnik, Bradbury, Barnes, \& Leff, 2014), 노화로 인해 설단현상이 나타났을 때 그것을 해결하는 시간 또한 길어진다고 알려져 있다
(Heine, Ober, \& Shenaut, 1999). 노화로 인한 설단현상은 음운 산 출 문제와 관련이 있으며(Park et al., 2013), 따라서 노인들은 목표 단어를 떠올리지 못할 때 의미를 설명하려는 특성을 보이거나 목표 단어와 유사한 범주의 특징들에 대해 우회적으로 설명하는 방식 을 사용한다고 알려져 있다(Barresi, Nicholas, Connor, Olber, \& Albert, 2000; Mortensen, Meyer, \& Humphreys, 2006).

일부의 연구에서 설단현상은 일반명사보다 사람 이름과 같은 고 유명사에서 더 많이 나타난다고 보고하고 있는데(Lee \& Choi, 2016; Papagno \& Capitani, 1998), 이는 일반명사가 고유명사에 비해 기 억체계 안에서의 상호연결이 많기 때문인 것으로 알려져 있다(Schaie \& Willis, 2020). 또한, 사람 이름대기는 일반명사 이름대기 과정과 는 다른 처리 과정을 거치는 것으로 알려져 있다(Robson, Marshall, Pring, Montagu, \& Chiat, 2004). 사람 이름대기의 처리 과정은 일 단 친숙한 얼굴을 보았을 때, 시각적 구조화를 통해 얼굴 인식 장치 (face recognition units)에서 해당 인물에 대한 의미 정보(직업, 성 격 등)가 활성화된다. 이때 사람의 이름은 의미 정보와 함께 활성화 되지 않으며, 별도의 음운 산출 체계를 거쳐 산출된다(Valentine, Brennen, \& Brédart, 1995). 따라서 노인들은 친숙한 사람의 얼굴 을 보았을 때, 사람에 대한 의미 정보는 떠올릴 수 있으나 이름의 음 운 형태를 검색할 수 없는 일이 종종 발생하게 되며(Papagno \& Capitani, 1998), 이러한 친숙한 사람 이름에 대한 설단현상은 노인들을 당황스럽고 짜증나게 하는 주요한 기억장애로 보고되고 있다(Cohen \& Faulkner, 1986; Lovelace \& Twohig, 1990). 사람 이름대기와 같은 고유명사에서의 노인들이 보이는 설단현상과 관련된 연구들 은 국내에서도 다양하게 이루어져 왔다(Kim, Kim, \& Yoon, 2020; Lee \& Choi, 2016; Oh \& Ha, 2015). 우선, 주관적 기억 장애(subjective memory complaints) 집단과 일반 노인을 대상으로 한 Kim 등 (2020)의 연구에 따르면 주관적 기억 장애 집단은 정상적 범주의 인 지기능을 가지고 있음에도 불구하고 일반 노인에 비해 더 높은 설 단율을 보였으며, 설단해결률 또한 낮은 것으로 나타났다. 다음으 로 청년과 노인을 대상으로 고유명사와 빈도에 따른 일반명사의 설 단현상을 비교한 Lee와 Choi (2016)의 연구에서는 노인에게서 높 은 설단율이 나타났으며, 일반명사보다는 고유명사에서, 고빈도어 보다는 저빈도어에서 설단현상이 증가했다고 보고하였다. 마지막 으로 20대부터 노인까지의 일반인과 경도인지장애(mild cognitive impairment) 환자를 대상으로 설단현상을 연구한 $\mathrm{Oh}$ 와 $\mathrm{Ha}$ (2015) 의 연구에 따르면 노화에 따라 설단현상이 증가하고, 경도인지장 애의 경우 일반 노인과 설단율 자체의 차이는 없으나 단서 활용 능 력이 제한된다고 보고하고 있다.

설단현상을 설명하는 불완전 활성화 가설과 전달 결함 가설의 
일부 공통되는 부분은 설단현상을 해결하기 위해서 단절 혹은 불 충분한 정보 전달을 보충하기 위한 단서가 필요하다는 점이다(Dahlgren, 1998; Schwartz, 1999). 특히, 청년은 목표단어의 첫 글자와 마 지막 글자에 대한 정보가 비슷하게 유지되는 것에 반해 노인은 목 표단어의 마지막 글자에 대한 정보가 첫 글자에 대한 정보에 비해 더 큰 손실을 보인다(Park et al., 2013). 따라서 노인의 경우 설단현 상을 경험하는 동안 의미 정보는 유지되고 떠오르지만, 음운 정보 산출에는 손실이 있으며(Brown \& Nix, 1996; Miozzo \& Caramaz$\mathrm{za}, 1997)$, 이를 해결하기 위해서는 음운 수준의 활성화를 촉진시킬 수 있는 단서가 필요하다. 이름대기 수행력 개선을 위한 단서 효과 를 알아본 선행 연구들의 결과를 살펴보면, 의미단서보다음절단서 를 제공했을 때 효과가 더 높은 것으로 알려져 있다(Kim, 2009). 이 와 관련하여 Delazer, Semenza, Reiner, Hofer와 Benke (2003)는 이 름대기 과제에서 의미단서, 음절단서, 객관식 단서를 제공하였을 때 음절단서의 효과가 가장 높았으며, 이러한 음절단서의 효과는 경도인지장애(mild cognitive impairment, $\mathrm{MCI}$ )와 알츠하이머형 치매(Dementia of Alzheimer's Type, DAT) 환자에게서도 동일하 게 나타났다고 보고하였다. 또한, 중증도에 따른 DAT 환자들의 이 름대기에서의 단서 활용 능력을 비교한 Kim 과 Choi (2012)의 연구 에서는 DAT의 중증도가 낮을수록 음절단서의 효과가 더 큰 것으 로 나타났다.

지금까지 살펴본 바와 같이 사람 이름대기에서의 설단현상은 정 상적인 노화과정에서 연령의 증가에 따라 다른 양상을 보이지만 노 화에 따른 설단현상의 변화를 보고한 연구는 제한적이며, 경도인지 장애(Oh \& Ha, 2015), 주관적 기억장애(subjective memory complaints, SMC) (Kim et al., 2020) 집단의 대조군으로 일반 노인의 연 령별 차이를 살펴본 연구들이 일부 존재하지만 연구 대상자의 수 가 제한적이었다. 또한 이름대기 수행력 개선을 위한 단서의 효과 를 알아보는 것은 임상적으로 대단히 중요하지만 설단현상을 해결 하는 과정에서 연령에 따른 단서 효과의 차이를 비교한 연구 또한 부족한 실정이다. 따라서 본 연구는 55 세에서 84 세 사이의 일반 노 인을 연령집단으로 구분하여 유명인 이름대기에서의 연령에 따른 설단현상 특성을 알아보는 것을 목적으로 하였다. 구체적인 연구 문제는 다음과 같다. 첫째, 연령집단과 설단유형(전체 인출 실패, 부 분 인출 실패)에 따른 설단율의 차이를 알아본다. 둘째, 연령집단에 따른 설단현상 반응유형 비율의 특성을 알아본다. 셋째, 연령집단 과 설단해결 유형(자발적 설단해결, 단서제공 후 설단해결)에 따른 설단해결률의 차이를 알아본다.

\section{연구방법}

\section{연구대상}

본 연구는 55세부터 84세까지의 일반 노인 96명(남성 37명, 여성 59명)을 대상으로 하였다. 연령집단은 55-64세, 65-74세, 75-84세로 구분하였으며, 55-64세 24명, 65-74세 30명, 75-84세 42명이 각 연령 집단에 포함되었다. 대상자의 선정기준은 한국판 간이정신상태 검 사(Korean Version of Mini-Mental State Examination, K-MMES; Kang, 2006) 결과 $16 \%$ ile 이상으로 연령과 교육년수 규준에서 정상 범위에 속하고, 주관적 기억 감퇴 설문(Subjective Memory Complaints Questionnaire, SMCQ) (Youn et al., 2009)에서 5점 이하로 주관적인 기억 장애가 없으며, 실어증 선별검사(Screening Test for Aphasia Neurologic communication Disorders, STAND; Kim, $\mathrm{Heo}, \mathrm{Kim}, \& \mathrm{Kim}, 2009)$ 의 하위 검사인 듣고 이해하기 검사 시 과 제 수행에 어려움이 없고, 신경.정신과적 질환의 경험이 없으며, 시 각 및 청각 등 감각에 이상이 없고, 단축형 노인 우울 척도(Short form of Geriatric Depression Scale, SGDS: Kee, 1996) 결과 7점 이 하로 우울증이 없는 자로 하였다. 연령집단에 따른 대상자의 성별, 연령, 교육년수, K-MMSE 및 SGDS 점수에 대한 기술 통계치를 Table 1 에 제시하였다.

우선 대상자의 연령집단에 따른 성비에 차이가 있는지 알아보기 위하여 카이제곱 분석을 실시한 결과, $\chi^{2}=.685$ ( $p>.05$ )로 성비의 차이는 유의하지 않았다. 다음으로 교육년수, K-MMSE 점수에 연 령집단에 따른 차이가 있는지 알아보기 위하여 분산의 동질성 확인 후 일원분산분석을 실시한 결과, 교육년수 $\left.\left(F_{(2,95)}\right)=4.303, p<.01\right)$ 와 K-MMSE 점수 $\left(F_{(2,95)}=4.225, p<.05\right)$ 모두 연령집단에 따른 차이 가 유의하였다. 사후분석 결과 교육년수의 차이는 55-64세 집단과 65-74세 집단, 55-64세 집단과 75-84세 집단에서 유의한 것으로 나 타났으며, K-MMSE 점수 차이는 55-64세 집단과 75-84세 집단 사 이에서만 유의한 것으로 나타났다.

Table 1. Gender, mean (SD) of age, education level, K-MMSE and SGDS score in participants

\begin{tabular}{lccc}
\hline & $\begin{array}{c}55-64 \text { years old } \\
(\mathrm{N}=24)\end{array}$ & \begin{tabular}{c}
$\begin{array}{c}65-74 \text { years old } \\
(\mathrm{N}=30)\end{array}$ \\
\hline Gender (Male:Female)
\end{tabular} & $\begin{array}{c}75-84 \text { years old } \\
(\mathrm{N}=42)\end{array}$ \\
Age (yr) & 60.15 & 10.20 & 18.24 \\
Education level (yr) & $11.13(3.79)$ & $71.93(2.75)$ & $80.69(1.87)$ \\
K-MMSE score & $26.88(1.48)$ & $25.63(4.03)$ & $8.43(3.86)$ \\
SGDS & $.83(1.47)$ & $1.20(1.27)$ & $25.19(2.70)$ \\
\hline
\end{tabular}

K-MMSE = Korean version of Mini-Mental State Examination (Kang, 2006); SGDS= Short form of Geriatric Depression Scale (Kee, 1996). 


\section{연구과제}

유명인 이름대기 과제는 $\mathrm{Oh}$ 와 $\mathrm{Ha}$ (2015)의 과제를 수정, 보완하 여 사용하였다. 유명인은 시대별로 1970년, 1980년, 1990년, 2000년 이후로 구분하였으며, 정치경제, 대중문화, 기타(사회, 예술, 체육) 로 나누어 각 범주별로 10 명씩 총 30 명을 선정하였다. 본 연구에서 사용된 유명인 이름 목록은 Appendix 1에 제시하였다. 다음으로 유명인의 사진은 McKenna와 Warrington (1980)의 기준에 따라 다음과 같이 선정하였다: 1) 인물이 사진으로 구별 가능해야 하고, 2) 한 명의 유명인만을 나타내는 사진이어야 하며, 3) 유명인을 알 아볼 수 있는 옷, 악세사리 등의 단서가 없고, 4) 과거 인물이라도 시 대에 상관없이 사람들이 알아볼 수 있어야 한다. 문항의 배열은 시 대별, 범주별, 고빈도순, 한글 자음순에 무관하게 무작위로 제시하 였다. 모든 유명인의 사진은 모자를 착용하지 않은 상반신 사진을 사용하였으며 동일한 크기로 제작하였다. 본 연구에서 사용된 유 명인 사진의 예를 Appendix 2에 제시하였다.

\section{연구절차}

본 연구는 나사렛대학교의 생명윤리위원회의 승인(No. 2019-217)과 연구 대상자의 서면 동의를 얻어 진행하였다. 자료수집은 소 음이 통제된 공간에서 개별적으로 진행하였다. 실험 시작 전 각 대 상자에게 2개의 연습문항을 실시한 후 본 실험에 들어갔으며, $\mathrm{Oh}$ 와 $\mathrm{Ha}$ (2015)의 실험 절차를 따랐다. 구체적인 시행절차는 다음과 같다. (1) 목표 유명인의 사진을 제시한 후 "이 사람을 본 적이 있나 요?”라고 질문을 한다. “있다”로 답한 경우 “이름이 무엇인가요?” 라고 재질문 한다. 15 초 안에 정답을 산출한 경우 정반응으로 간주 하고 다음 문항으로 넘어간다(설단현상 아님). 해당 유명인에 대해 본 적이 “없다"라고 답한 경우 검사자는 오반응으로 간주하고 다 음 문항으로 넘어간다(설단현상 아님). (2) “있다”로 답하였으나, 15 초 안에 정답을 산출하지 못한 경우 설단현상이 일어난 것으로 판 단한다. 설단현상이 나타나면 대상자가 이름을 전혀 말하지 못한 경우(전체 인출 실패)와 이름을 부분적으로 인출한 경우(부분 인 출 실패)로 구분하고, 추가적인 설명을 요구한다. (3) 추가적인 설명 도중 자발적으로 설단해결이 나타난 경우 검사자는 그 문항에 대 한 검사를 중지하고 다음 문항으로 넘어간다(자발적 설단해결). (4) 목표 유명인에 대해 부적절한 설명을 한 경우 추가적인 설명을 요 구한다. 재시도에도 불구하고 오반응 및 무반응을 보일 경우 검사 자는 그 문항에 대한 검사를 중지하고 다음 문항으로 넘어간다(자 발적 설단해결 실패). (5) 자발적 설단해결 실패 문항에 대하여 음절 단서를 제공한다. 음절단서는 기본적으로 첫 음절을 제공하며, 부 분 인출 실패에서 첫 음절을 대상자가 산출한 경우, 끝 음절로 단서
를 제공한다. 단서 제공 시 정반응이 나타난 경우 다음 문항으로 넘 어간다(단서 제공으로 인한 설단해결). 단서 제공 후에도 정반응이 나타나지 않은 경우 다음 문항으로 넘어간다(설단해결 실패).

신뢰도 분석은 전체 대상자의 $20 \%$ 에 해당하는 자료를 무작위로 추출하여 실시하였으며, 해당 자료를 제 1 평가자(연구자)와 제 2 평가 자(언어치료학 대학원에 진학 중인 2 급 언어치료사) 1 명이 각각 분 석하였다. 제 1 평가자와 제 2 평가자의 일치도는 $93.3 \%$ 로 나타났다.

\section{자료분석}

유명인 이름대기의 설단현상 특성을 분석하기 위하여 설단율 (부분 인출 실패, 전체 인출 실패), 설단현상 반응유형 비율, 설단해 결률(자발적 설단해결, 단서제시 후 설단해결)을 분석하였다. 우선 설단율은 이름을 말하지 못하거나 오반응한 항목수를 '본 적 있음' 으로 응답한 항목 수로 나누고 100을 곱하여 계산하며, 목표 이름 의 전체를 말하지 못하는 전체 인출 실패와 이름의 한 글자 이상을 인출하였으나 정확한 이름을 산출하지 못한 부분 인출 실패로 나 누어 분석하였다. 다음으로, 설단현상 반응유형 비율은 설단현상 발생 후 목표 유명인에 대해 자발적으로 설명하는 유형별 설단현상 의 반응 수를 설단현상의 총 반응 수로 나눈 후 100 을 곱하여 분석 하였다. 반응유형 분류는 Oh와 $\mathrm{Ha}$ (2015)의 연구를 기초로 하여 '직업, 관련인, 관련사건, 유사이름, 기타 인출 노력'의 5 유형으로 분 류하였으며, 반응유형의 구체적인 예는 Appendix 3에 제시하였다. 마지막으로 설단해결률은 설단현상 발생 후 설단현상을 해결하여 정반응한 경우를 의미하며, 설단현상이 해결된 항목 수를 설단현 상이 나타난 항목 수로 나눈 후 100 을 곱하여 계산하였다. 설단해 결률은 자발적으로 설단현상을 해결한 경우와 음절단서 제시 후 해결한 경우로 나누어 분석하였다. 설단현상에 대한 구체적인 산 출 공식은 Appendix 4에 제시하였다.

\section{통계분석}

본 연구의 모든 통계 분석은 SPSS 22.0 프로그램을 사용하였다. 우선, 연령집단에 따른 유명인 인식률에 차이가 통계적으로 유의한 지 알아보기 위하여 일원분산분석(one-way ANOVA)을 실시하고 사후분석(Scheffe)을 실시하였다. 다음으로, 연령집단과 설단유형 (전체 인출 실패, 부분 인출 실패)에 따른 설단율의 차이를 알아보 기 위하여 교육년수를 공변량으로 한 연령집단(3)과 설단유형(2)의 혼합분산분석(mixed ANOVA)을 실시하고, Bonferroni 교정을 통 한 다중비교(multiple comparisons)를 실시하였다. 마지막으로 연 령집단과 설단해결 유형(자발적 설단해결, 단서제공 후 설단해결) 에 따른 설단해결률의 차이를 알아보기 위하여 교육년수를 공변량 
으로 한 연령집단(3)과 설단해결률 유형(2)의 혼합분산분석을 실시 하고, Bonferroni 교정을 통한 다중비교(multiple comparisons)를 실시하였다.

\section{연구결과}

\section{연령집단에 따른 설단율의 차이}

일반 노인의 연령집단에 따른 설단율 비교에 앞서 과제에서 '본 적 있음으로 응답한 유명인 인식률을 Table 2에 제시하였다. 결과 를 구체적으로 살펴보면 유명인 인식률은 연령이 증가할수록 감소 하였지만 75-84세 집단에서도 90\% 정도로 상당히 높게 나타났다. 연령집단에 따른 유명인 인식률에 차이가 통계적으로 유의한지 알 아보기 위하여 분산의 동질성 검정을 실시한 결과 분산의 동질성 을 가정하지 않아 $(p<.05)$ Welch의 평균 동질성 검정으로 집단 간 의 차이를 검정하였다. 그 결과 연령집단 간 평균 차이는 유의한 것 으로 나타났으며 $(p<.001)$, 사후 분석(Games-Howell) 결과 유의한 차이는 55-64세와 65-74세 사이, 55-64세와 75-84세 집단 사이에 서 나타났다 $(p<.05)$.

다음으로 연령집단에 따른 총 설단율을 Figure 1에, 전체 인출 실 패, 부분 인출 실패로 인한 설단율의 기술통계치를 Table 3에 제시 하였다. 결과를 살펴보면 연령이 증가함에 따라 총 설단율과 전체 인출 실패로 인한 설단율이 증가하였으며, 모든 연령집단에서 전체 인출 실패로 인한 설단율이 부분 인출 실패로 인한 설단율보다 높

Table 2. Mean (SD) of celebrity recognition rate by age group

\begin{tabular}{lcc}
\hline & Mean $(\%)$ & SD $(\%)$ \\
\hline $55-64$ years old $(N=24)$ & 97.50 & 4.84 \\
$65-74$ years old $(N=30)$ & 92.44 & 7.68 \\
$75-84$ years old $(N=42)$ & 90.32 & 9.28 \\
\hline
\end{tabular}

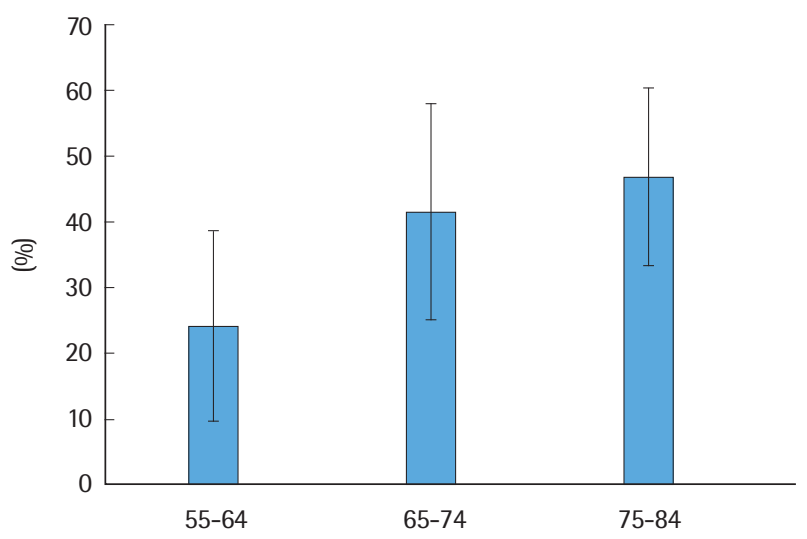

Figure 1. Mean of total tip of the tongue (TOT) rate by age group.
은 것으로 나타났다. 연령집단과 설단유형(전체 인출 실패, 부분 인 출 실패)에 따른 설단율의 차이를 살펴보기 위하여 교육년수를 공 변량으로 한 혼합분산분석을 실시한 결과, 연령집단 $\left(F_{(2,92)}=12.865\right.$, $p<.001)$ 과 설단유형 $\left(F_{(2,92)}=39.591, p<.001\right)$ 에 따른 주효과가 모두 유의하였으며, 집단에 따른 차이는 55-64세와 65-74세 집단, 55-64 세와 75-84세 집단에서 유의한 것으로 나타났다 $(p<.05)$. 마지막으 로, 연령집단과 설단유형의 상호작용 효과 또한 유의한 것으로 나 타났다 $\left(F_{(2,92)}=7.155, p<.01\right)$.

\section{연령집단에 따른 설단현상 반응유형 비율의 특성}

연령집단에 따른 설단현상의 총 반응 수에 대한 기술통계치를 Table 4에 제시하였다. 또한, 연령집단에 따른 설단현상 총 반응 수 에 있어서 통계적으로 유의한 차이가 있는지 알아보기 위하여 분 산의 동질성 확인 후 일원분산분석을 실시한 결과, 연령집단 간 차 이는 유의하지 않은 것으로 나타났다 $\left(F_{(2,95)}=.274, p>.05\right)$. 다음으 로, 연령집단에 따른 설단현상의 반응유형(직업, 관련인, 관련사건,

Table 3. Mean (SD) of the whole retrieval failure and partial retrieval failure rate by age group

\begin{tabular}{lccc}
\hline & $\begin{array}{c}55-64 \text { years old } \\
(\mathrm{N}=24)\end{array}$ & $\begin{array}{c}65-74 \text { years old } \\
(\mathrm{N}=30)\end{array}$ & $\begin{array}{c}75-84 \text { years old } \\
(\mathrm{N}=42)\end{array}$ \\
\hline Whole retrieval failure $(\%)$ & $18.00(12.41)$ & $33.20(16.94)$ & $38.54(13.85)$ \\
Partial retrieval failure $(\%)$ & $6.19(6.00)$ & $8.35(5.99)$ & $8.28(5.65)$ \\
\hline
\end{tabular}

Table 4. Mean (SD) of total number of response in tip of the tongue (TOT) by age group

\begin{tabular}{lcc}
\hline & Mean & SD \\
\hline $55-64$ years old $(N=24)$ & 3.25 & 1.07 \\
$65-74$ years old $(N=30)$ & 3.40 & 0.81 \\
$75-84$ years old $(N=42)$ & 3.24 & 1.01 \\
\hline
\end{tabular}

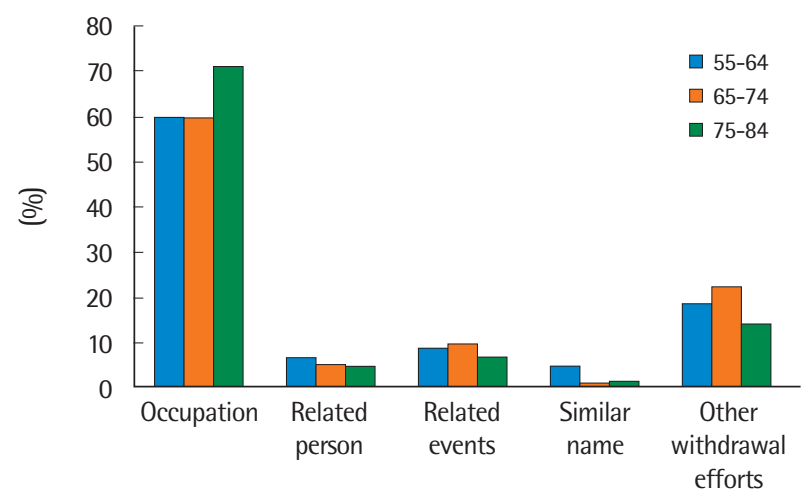

Figure 2. Mean response rate according to response type of tip of the tongue (TOT) among age groups. 


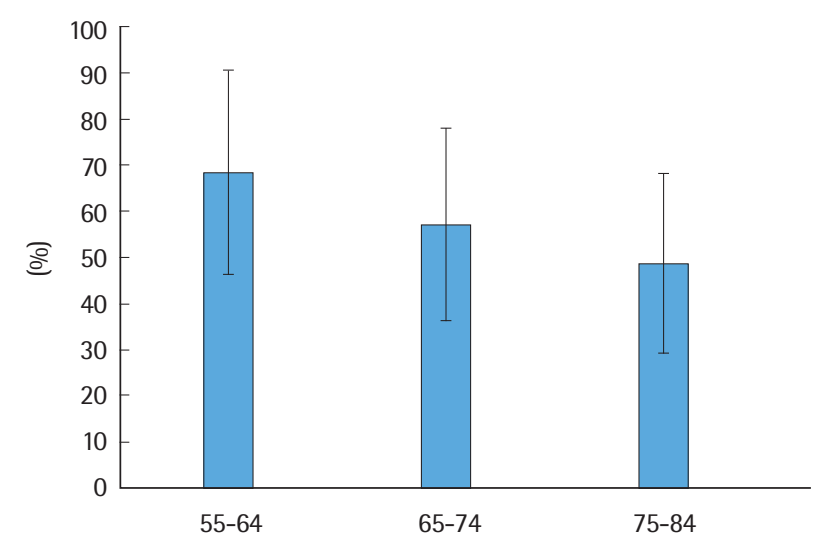

Figure 3. Mean of total tip of the tongue (TOT) solution rate by age group.

유사이름, 기타 인출 노력)에 따른 평균 산출 비율을 Figure 2에 제 시하였다. 반응유형의 산출 비율은 세 집단 모두 직업, 기타 인출노 력, 관련 사건, 관련인, 유사이름의 순으로 높게 나타났다. 연령집단 에 따른 특성을 살펴보면 직업 유형의 경우 75-84세 집단의 산출 비 율이 다른 집단에 비해 높았으며, 반대로 기타인출 반응유형의 경 우 75-84세 집단의 산출 비율이 다른 집단에 비해 낮게 나타났다.

\section{연령집단 간 설단해결률 차이}

연령집단에 따른 총 설단해결률을 Figure 3에, 자발적 설단해결 률, 음절단서 제시 후 설단해결률과 설단해결 실패율의 기술통계치 를 Table 5에 제시하였다. 결과를 살펴보면 연령이 증가할수록 총 설단해결률, 자발적 설단해결률, 음절단서 제시 후 설단해결률 모 두 감소하였으며, 모든 연령집단에서 음절단서 제시 후 설단해결률 이 자발적 설단해결률에 비해 높은 것으로 나타났다. 연령집단과 설단해결률 유형에 따른 차이를 살펴보기 위하여 교육년수를 공변 량으로 한 혼합분산분석을 실시한 결과, 연령집단 $\left(F_{(2,92)}=5.894\right.$, $p<.01)$ 과 설단해결 유형 $\left(F_{(2,92)}=30.585, p<.001\right)$ 에 따른 주효과가 모두 유의하였으며, 집단에 따른 차이는 55-64세와 75-84세 집단에 서만 유의한 것으로 나타났다 $(p<.05)$. 마지막으로, 집단과 설단해 결 유형의 상호작용 효과는 유의하지 않은 것으로 나타났다 $\left(F_{(2,92)}=\right.$ $.179, p>.05)$.

\section{논의 및 결론}

본 연구는 55-64세, 65-74세, 75-84세 집단의 일반 노인을 대상으 로 유명인 이름대기 과제를 실시하여 연령집단에 따른 설단율, 설 단현상의 반응유형, 설단해결률의 차이를 알아보는 것을 목적으로 하였다. 구체적인 결과는 다음과 같다. 첫째 연령이 증가함에 따라
Table 5. Mean (SD) of the voluntary TOT solution rate, TOT solution rate after presentation of syllabic clues and failure rate of TOT solution by age group

\begin{tabular}{cccc}
\hline & $55-64$ years old & $65-74$ years old & $75-84$ years old \\
& $(\mathrm{N}=24)$ & $(\mathrm{N}=30)$ & $(\mathrm{N}=42)$ \\
\hline $\begin{array}{c}\text { Voluntary TOT solution rate }(\%) \\
\text { TOT solution rate (\%) after } \\
\text { presentation of syllabic clues }\end{array}$ & $27.56(25.52)$ & $20.61(16.56)$ & $13.58(12.30)$ \\
Failure rate of TOT solution (\%) & $31.50(22.56)$ & $36.48(17.34)$ & $35.20(14.68)$ \\
\hline
\end{tabular}

TOT = Tip of the Tongue.

총 설단율이 증가하였으며, 연령집단에 따른 설단율의 차이가 유의 한 것으로 나타났다. 이는 고령자의 설단현상을 연구한 국내외의 많은 연구들과 일치하는 결과이다(Burke et al., 1991; Evrard, 2002; Heine et al., 1999; Kim et al., 2020; Lee \& Choi 2016; Oh \& Ha, 2015; Park et al., 2013). 사후검정 결과, 설단율의 경우 55-64세와 65-74세, 55-64세와 75-84세 집단 사이의 차이는 유의하였으나, 65-74세와 75-84세 집단 사이의 차이는 유의하지 않았다. 이는 상 대적으로 젊은 노인과 65 세 이상의 노인 연령집단 사이의 설단율 차이가 유의하게 나타난 것으로, 일반 노인의 경우 70 세 이상에서 이름대기의 어려움이 급격히 나타난다는 선행연구의 결과(Hodgson \& Ellis, 1998; Verhaegen \& Poncelet, 2013)와 관련지어 설명할 수 있다. 유형별 설단율의 산출 비율을 살펴보면 모든 연령집단에 서 전체 인출 실패로 인한 설단율이 부분 인출 실패로 인한 설단율 에 비해 월등히 높았는데, 이렇듯 전체 인출 실패로 인한 설단율이 높은 이유는 노화로 인한 전달 결함과 관련하여 설명할 수 있다 (Burke et al., 1991; Burke \& Shafto, 2004). 전달 결함 가설에 따르면 목표단어에 대한 점화 전달의 곤란이 단어 인출 실패의 원인이며, 이때 목표단어의 점화 전달은 부분적으로 실패하기보다는 전체적 으로 나타나지 않는 경우가 많다. 또한, 부분적으로 점화 전달이 일 어난 경우에는 산출 시간이 다소 지연되더라도 많은 경우 단어인 출에 성공하기 때문에 설단현상을 경험하지 않게 된다. 다음으로 연령집단과 설단유형의 상호작용 효과 또한 유의한 것으로 나타났 는데, 이는 연령이 증가할수록 부분 인출 실패로 인한 설단율에 비 해 전체 인출 실패로 인한 설단율의 비율이 현격히 높아진 것과 관 련이 있음을 유추할 수 있다.

둘째, 연령집단 간 설단현상 반응유형의 산출 비율을 비교한 결 과 반응유형의 산출 비율은 세 집단 모두 직업, 기타 인출 노력, 관 련 사건, 관련인, 유사이름의 순으로 높게 나타났다. 본 연구에서 연 령집단에 관계없이 직업을 설명하는 반응유형의 산출 비율이 가장 높았는데, 이러한 결과는 본 연구와 유사한 유명인 이름대기 과제 를 사용한 기존의 연구결과( $\mathrm{Oh} \& \mathrm{Ha}, 2015)$ 와 일치하며, 이러한 양 상은 연령과 관계없이 동일하게 나타남을 알 수 있다. 이는 인물을 
떠올릴 때 그 인물과 관련된 의미정보 중 직업과 관련된 정보가 가 장 핵심적이며, 가장 많이 활성화되는 정보임을 시사한다. 다만, 이 러한 직업과 관련된 정보가 가장 높은 반응유형 비율을 보인 것은 이름대기의 대상이 본인 주변의 인물이 아닌 유명인이었으며, 유명 인의 경우 상대적으로 직업과 관련된 정보가 가장 중요한 인물의 특성이기 때문에 나타난 현상일 수도 있으므로 해석에 유의할 필 요가 있다. 다음으로 모든 연령집단에서 기타 인출 노력의 산출 비 율이 높았는데, 기타 인출 노력의 많은 부분은 이름이 생각나지 않 는 것에 대한 개인적인 정서 표현(예, "아 이 사람 아는 사람인데”...) 으로, 이는 설단현상이 나타났을 때의 당혹감을 표현하는 공통적 인 반응으로 여겨진다. 나머지 반응유형의 빈도는 제한적으로 나 타났다. 다음으로 연령집단에 따른 반응유형의 특징을 살펴보면 우선 직업 유형의 경우 75-84세의 고령 집단의 산출 비율이 다른 집단에 비해 높고, 상대적으로 기타인출 반응유형의 산출이 낮았 는데, 이는 연령이 증가할수록 가장 많은 설단현상의 반응유형인 직업을 설명하는 반응이 증가함을 의미하며(Beier \& Ackerman, 2001), 설단현상이 증가함에도 불구하고 단어의 주요 의미 정보에 대한 산출 능력은 고령노인에게 수행이 감소하지 않고 오히려 증가 하는 경향을 보인다는 선행연구에 빗대어 설명할 수 있다(Burke et al., 1991). 다음으로 실험에 참여했던 대상자들은 설단현상을 경험 하는 동안 목표 유명인의 이름에 대해 음운 정보 산출에는 어려움 을 보였으나, 의미 정보 산출은 어느 정도 가능하였다. 이는 설단현 상을 경험하는 동안 목표단어에 대해 음운 정보는 완전히 또는 부 분적으로 떠오르지 않지만, 의미 관련 정보는 어느 정도 인출이 가 능하다는 선행연구(Brown \& McNeill, 1966; Miozzo \& Caramaz$\mathrm{za}, 1997)$ 와 일치하는 결과이다.

셋째, 정상적 노화과정에서 연령집단에 따라 설단해결률에 차이 가 있는지를 살펴보았으며, 설단해결률은 자발적 설단해결률과 음 절단서 제시 후 설단해결률로 구분하였다. 우선, 자발적 설단해결 률은 연령집단에 따른 차이가 유의하였으며, 그 차이는 55-64세와 75-84세 사이에서만 나타났다. 이는 연령이 증가함에 따라 설단해 결률이 낮아진다는 기존의 연구결과와 일치하는 결과이다(Heine et al., 1999; Oh \& Ha, 2015). 사후분석 결과 자발적 설단해결률의 차이가 모든 집단에서 유의하지는 않았지만, 연령이 증가함에 따 라 자발적 설단해결률이 저하되었다. 설단현상을 설명하는 불완전 활성화 가설에 따르면 설단현상을 경험하는 상황일지라도 불활성 화된 기억의 강도가 증가하거나 변화하면 설단현상을 해결하게 되 는 경우도 있는데(Schwartz, 1999), 노화로 인해 목표단어의 회상 능력이 제한되고, 기억의 활성화 수준 또한 저하되어 설단해결에 어려움을 보임을 알 수 있다. 음절단서를 제공하였을 때의 설단해
결률 역시 연령이 증가함에 따라 감소하였는데, 이를 통하여 노화 로 인한 인지기능의 저하가 단서 활용 능력에도 영향을 미침을 알 수 있다. 이와 관련하여 일반 노인과 경도인지장애(MCI) 환자 집단 을 대상으로 한 Oh와 $\mathrm{Ha}$ (2015)의 연구에서 두 집단의 설단율에 있어서의 차이는 유의하지 않았음에도 불구하고, 음절단서의 활용 능력은 차이를 보였다. 즉, 인지기능 장애로 인하여 단서 활용 능력 이 제한된 것인데, 본 연구의 결과를 통하여 단서 활용 능력의 제한 은 정상적인 노화 과정에서도 나타남을 알 수 있다. 다음으로 유형 에 따른 설단해결률을 비교하면, 자발적 설단해결률이 연령집단에 따라 $13-28 \%$ 정도인 것에 비해 음절단서를 제공하였을 때의 설단 해결률은 35-40\% 정도로 나타났다. 이러한 결과는 설단현상에서 의 단서효과를 증명하는 것으로, 특히 음절단서 제공 후에 설단해 결률이 증가한다는 기존의 연구결과와 일치한다(Lee \& Choi, 2016; $\mathrm{Oh} \& \mathrm{Ha}, 2015)$. 음절단서 제공 후 설단해결률 역시 연령집단에 따 른 차이가 유의하였으며, 그 차이는 55-64세와 75-84세 사이에서 나타났다. 이는 목표단어의 첫 음절을 단서로 제시할 경우 정반응 을 증가시킨다는 선행연구의 결과(Hayles, Katherine, \& Hayles, 2002)와 일치하며, 노화로 인해 설단현상이 발생하더라도 적절한 음절단서가 제공되면 목표단어의 활성화를 촉진시켜 설단현상이 어느 정도 해결될 수 있음을 시사한다(Burke et al., 1991; Rastle \& Burke, 1996; White \& Abrams, 2002). 또한, 설단현상의 해결을 위 해서는 단서 제공이 필요하고, 음운 수준의 단서가 보다 효과적이 라는 선행연구(Lee \& Choi, 2016)와 같은 맥락으로 설명된다. 본 연 구에서는 설단현상이 발생하였을 때, 음절단서처럼 점화 전달을 활 성화시킬 수 있는 단서를 제시하면 고령노인의 경우에도 50\% 정도 설단현상을 해결할 수 있다는 점을 밝혔는데, 이는 설단현상에서 의 음운단서의 중요성을 시사한다.

본 연구에서는 일반 노인을 연령집단으로 구분하여 정상적인 노 화에 따른 설단현상의 특성을 살펴보았다. 또한, 설단현상 발생 시 나타나는 반응유형과 음절단서 제공 시 음운 활성화를 통한 설단 해결의 가능성을 엿보았다. 일부 연구에서 노화로 인한 집행기능 및 기억능력 저하와 같은 인지기능의 문제 역시 중재를 통하여 개 선 효과를 기대할 수 있다고 보고하고 있다(Insel, Einstein, Morrow, Koerner, \& Hepworth, 2016). 이러한 관점에서 본 연구의 결과 는 정상적인 노화과정에서 나타나는 의사소통 능력의 변화를 파 악하고, 효과적인 의사소통 방법을 제안할 수 있다는 임상적 의의 를 지닌다. 또한, 본 연구를 통하여 설단현상 해결 시 단서 제공의 중요성을 알 수 있었으며, 이러한 결과는 노년층의 설단현상을 포함 한 이름대기 손상에 대한 평가와 치료계획을 수립하는데 임상적인 기초자료로 사용할 수 있을 것으로 사료된다. 그러나 유명인 이름 
Soojung Kim, et al. • Characteristics of Tip of the Tongue Phenomenon in Healthy Elderly

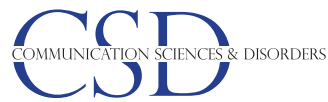

대기 과제의 경우 문화, 교육년수, 성별 등에 따른 차이가 나타날 가 능성이 있으므로 본 연구에서 설단현상을 유명인 이름대기에 국한 한 것은 아쉬움으로 남는다. 또한, 설단현상이 나타나는 일반명사 혹은 인물 이외의 고유명사들을 다각적으로 살펴보지 못한 점, 음 절단서 이외의 단서 효과를 살펴보지 못한 점 등을 연구의 제한점 으로 들 수 있다. 추후 이러한 제한점을 보완하여 후속 연구들이 진 행되기를 기대한다.

\section{REFERENCES}

Barresi, B. A., Nicholas, M., Connor, L. T., Olber, L. K., \& Albert, M. L. (2000). Semantic degradation and lexical access in age-related naming failures. Aging, Neuropsychology, and Cognition, 7(3), 169-178.

Beier, M. E., \& Ackerman, P. L. (2001). Current-events knowledge in adults: an investigation of age, intelligence, and nonability determinants. Psychology and Aging, 16(4), 615-628.

Bowles, N. L. (1993). Semantic process that serve picture naming. In J. Cerella, J. Rybash, W. Hoyer, \& M. L. Commons (Eds.), Adult information processing: limit on loss (pp. 303-326). San Diego, CA: Academic Press.

Brown, R., \& McNeill, D. (1966). The "tip of the tongue" phenomenon. Journal of Verbal Learning and Verbal Behavior, 5(4), 325-337.

Brown, A. S., \& Nix, L. A. (1996). Age-related changes in the tip-of-the-tongue experience. The American Journal of Psychology, 109(1), 79-91.

Burke, D. M., MacKay, D. G., Worthley, J. S., \& Wade, E. (1991). On the tip of the tongue: what causes word finding failures in young and older adults? Journal of Memory and Language, 30(5), 542-579.

Burke, D. M., \& Shafto, M. A. (2004). Aging and language production. Current Directions in Psychological Science, 13(1), 21-24.

Cohen, G., \& Faulkner, D. (1986). Memory for proper names: age differences in retrieval. British Journal of Developmental Psychology, 4(2), 187-197.

Dahlgren, D. J. (1998). Impact of knowledge and age on tip-of-the-tongue rates. Experimental Aging Research, 24(2), 139-153.

Delazer, M., Semenza, C., Reiner, M., Hofer, R., \& Benke, T. (2003). Anomia for people names in DAT-evidence for semantic and post semantic impairments. Neuropsychologia, 41, 1593-1598.

Ecke, P., \& Garrett, M. F. (1998). Lexical retrieval stages of momentarily inaccessible foreign language words1. Itha do Desterro A Journal of English Language, Literatures in English and Cultural Studies, 35, 157-183.

Evrard, M. (2002). Ageing and lexical access to common and proper names in picture naming. Brain and Language, 81(1-3), 174-179.
Hayles, N. K., Katherine, N., \& Hayles, B. (2002). Writing machines. Cambridge, MA: MIT Press.

Heine, M. K., Ober, B. A., \& Shenaut, G. K. (1999). Naturally occurring and experimentally induced tip-of-tongue experiences in three adult age groups. Psychology and Aging, 14(3), 445-457.

Hodgson, C., \& Ellis, A. W. (1998). Last in, first to go: age of acquisition and naming in the elderly. Brain and Language, 64(1), 146-163.

Insel, K. C., Einstein, G. O., Morrow, D. G., Koerner, K. M., \& Hepworth, J. T. (2016). Multifaceted prospective memory intervention to improve medication adherence. Journal of the American Geriatrics Society, 64(3), 561568.

Kang, Y. W. (2006). A normative study of the Korean-Mini Mental State Examination (K-MMSE) in the elderly. Korean Journal of Psychology, 25(2), $1-12$.

Kee, B. S. (1996). A preliminary study for the standardization of geriatric depression scale short form-Korea version. Journal of Korean Neuropsychiatric Association, 35(2), 298-307.

Kim, H. H., Heo, J. H., Kim, D. Y., \& Kim, J. W. (2009). Screening test for aphasia and neurologic-communication disorders (STAND). Seoul: Hakjisa.

Kim, H. J., \& Choi, H. J. (2012). A comparison on the naming abilities by modality in patients with Alzhiemer's disease. Dementia and Neurocognitive Disorders, 11(2), 53-58.

Kim, J., \& Kim, H. (2009). Communicative ability in normal aging: a review. Korean Journal of Communication \& Disorders, 14(4), 495-513.

Kim, J., Kim, M., \& Yoon, J. H. (2020). The tip-of-the-tongue phenomenon in older adults with subjective memory complaints. Plos one, 15(9), e0239327.

Kim, J. W., Hwang, J. H., Kim, S. R., \& Kim, H. (2013). Differences in attention and naming ability with age in the elderly. Journal of Speech and Hearing Disorders, 22(3), 25-44.

Kim, M. J. (2009). Famous people naming and identification ability depending on severity in Alzheimer's disease (Master's thesis). Ewha Womans University, Seoul, Korea.

LaBarge, E., Edwards, D., \& Knesevich, J. W. (1986). Performance of normal elderly on the Boston Naming Test. Brain and Language, 27(2), 380-384.

Lee, K. E., \& Lee, H. W. (2011). The effect of aging on retrieval of orthographic knowledge. Korean Journal of Cognitive and Biological Psychology, 23(4), 549-564.

Lee, Y. N., \& Choi, S. Y. (2016). Differences in tip-of-the-tongue phenomenon and resolving patterns according to vocabulary characteristics between young and elderly adults. Communication Sciences and Disorders, 21(1), 
139-150.

Lovelace, E. A., \& Twohig, P. T. (1990). Healthy older adults' perceptions of their memory functioning and use of mnemonics. Bulletin of the Psychonomic Society, 28(2), 115-118.

MacKay, D. G., \& Abrams, L. (1998). Age-linked declines in retrieving orthographic knowledge: empirical, practical, and theoretical implications. Psychology and Aging, 13(4), 647-662.

McKenna, P. A. T., \& Warrington, E. K. (1980). Testing for nominal dysphasia. Journal of Neurology, Neurosurgery and Psychiatry, 43(9), 781-788.

Miozzo, M., \& Caramazza, A. (1997). Retrieval of lexical-syntactic features in tip-of-the tongue states. Journal of Experimental Psychology: Learning, Memory, and Cognition, 23(6), 1410-1423.

Mortensen, A., Meyer, A. S., \& Humphreys, G. W. (2006). Age-related effects on speech production: a review. Language and Cognitive Processes, 21(1-3), 238-290.

Oh, S. A., \& Ha, J. W. (2015). The effects of aging and mild cognitive impairment on the tip-of-the-tongue phenomenon in people naming task. Dementia and Neurocognitive Disorders, 14(1), 39-47.

Papagno, C., \& Capitani, E. (1998). Proper name anomia: a case with sparing of the first-letter knowledge. Neuropsychologia, 36(7), 669-679.

Park, H., Shin, H. J., \& Son, M. D. (2012). A study of language disorders and language rehabilitation perceptions in elderly. Journal of Speech-Language and Hearing Disorders, 21(4), 227-247.

Park, J. Y., Lee, K. E., \& Lee, H. W. (2013). The effects of aging on retrieval of phonological knowledge in Korean: the tip-of-the-tongue phenomenon in young and older adults. Korean Journal of Cognitive Science, 24(2), 111132.

Rastle, K. G., \& Burke, D. M. (1996). Priming the tip of the tongue: effects of prior processing on word retrieval in young and older adults. Journal of Memory and Language, 35(4), 586-605.

Resnik, K., Bradbury, D., Barnes, G. R., \& Leff, A. P. (2014). Between thought and expression, a magnetoencephalography study of the "tip-of-the-tongue" phenomenon. Journal of Cognitive Neuroscience, 26(10), 2210-2223.
Robson, J., Marshall, J., Pring, T., Montagu, A., \& Chiat, S. (2004). Processing proper nouns in aphasia: evidence from assessment and therapy. Aphasiology, 18(10), 917-935.

Ryan, E. B., See, S. K., Meneer, W. B., \& Trovato, D. (1992). Age-based perceptions of language performance among younger and older adults. Communication Research, 19(4), 423-443.

Schwartz, B. L. (1999). Sparkling at the end of the tongue: the etiology of tipof-the-tongue phenomenology. Psychonomic Bulletin and Review, 6(3), 379-393

Statistics Korea. (2019). Elderly person statistics. Retrieved from http://www. kostat.go.kr.

Schaie, K. W., \& Willis, S. L. (2020). Handbook of the psychology of aging. Burlington, MA: Academic Press.

Tsang, H. L., \& Lee, T. M. (2003). The effect of ageing on confrontational naming ability. Archives of Clinical Neuropsychology, 18(1), 81-89.

Ulatowska, H. K., Chapman, S. B., Highley, A. P., \& Prince, J. (1998). Discourse in healthy old-elderly adults: a longitudinal study. Aphasiology, 12(7-8), 619-633.

Valentine, T., Brennen, T., \& Brédart, S. (1995). Cognitive psychology of proper names. London: Routledge.

Verhaegen, C., \& Poncelet, M. (2013). Changes in naming and semantic abilities with aging from 50 to 90 years. Journal of the International Neuropsychological Society, 19(2), 119-126.

White, K. K., \& Abrams, L. (2002). Does priming specific syllables during tip-of-the-tongue states facilitate word retrieval in older adults?. Psychology and Aging, 17(2), 226-235.

Youn, J. C., Kim, K. W., Lee, D. Y., Jhoo, J. H., Lee, S. B., Park, J. H., ... \& Woo, J. I. (2009). Development of the subjective memory complaints questionnaire. Dementia and Geriatric Cognitive Disorders, 27(4), 310-317.

Zec, R. F., Markwell, S. J., Burkett, N. R., \& Larsen, D. L. (2005). A longitudinal study of confrontation naming in the "normal" elderly. Journal of the International Neuropsychological Society, 11(6), 716-726. 
Appendix 1. 유명인 이름 목록

\begin{tabular}{lcccc}
\hline & 1970 & 1980 & 1990 & 2000 이후 \\
\hline 정치경제(10명) & 박정희, 김일성 & 전두환, 이건희 & 김대중, 김정일, 김영삼 & 노무현, 박근혜, 안철수 \\
대중문화(10명) & 이미자, 나훈아 & 이주일, 조용필, 최불암 & 김건모, 최진실, 차인표 & 유재석, 강호동 \\
기타: 사회, 예술, 체육(10명) & 차범근, 김수환 & 이만기 & 박찬호, 이봉주, 박세리, 황영조 & 김연아, 박태환, 박지성 \\
\hline
\end{tabular}

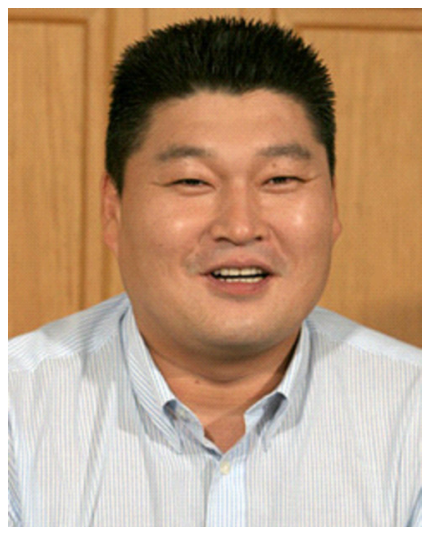

Appendix 2. 유명인 사진 예시

Appendix 3. 설단현상 반응유형

\begin{tabular}{ll}
\hline 항목 & \\
\hline 직업 & - 추기경, 이북 대통령, 운동선수, 노래하는 사람, 연기하는 사람, 삼성회장 등 \\
관련인 & - (이건희)의 예: 이병철 아들, 이재용 아버지 등 \\
관련사건 & - (유재석)의 예: 메뚜기(별명), 대상 받았잖아 등 \\
유사이름 & - (김연아)의 예: 김은아/김언아/이연아 등 (2음절 이상 알맞게 산출) \\
기타 인출 노력 & - 이름 인출 노력: (김연아)의 예; 김.....은아...언아... 등 \\
& - 개인적 경험: 이 사람한테 꽃다발 받아봤어 등 \\
& - 적절한 반응 못 함: 음..., 아... 이 사람 아는데 등 \\
& - 이 외 기타반응 \\
\hline
\end{tabular}

Appendix 4. 설단현상의 산출 공식

\footnotetext{
설단율 $(\%)=($ 이름을 말하지 못하거나 오반응한 수/본적있음' 항목수 $) \times 100$

- 전체 인출 실패로 인한 설단율 $(\%)=($ 전체인출 실패 항목수/본적있음' 항목수 $) \times 100$

- 부분 인출 실패로 인한 설단율 $(\%)=($ 부분인출 실패 항목수/본적있음' 항목수 $) \times 100$ 설단현상 반응유형 비율 $(\%)=($ 유형별 설단현상의 반응수/설단현상의 총 반응수 $) \times 100$ 설단해결률 $(\%)=($ 설단해결 항목수/설단현상이 나타난 항목수 $) \times 100$

- 자발적 설단해결률 $(\%)=($ 자발적 설단해결 항목수/설단현상이 나타난 항목수 $) \times 100$

- 음절단서 후 설단해결률 $(\%)=($ 음절 단서 후 설단해결 항목수/설단현상이 나타난 항목수 $) \times 100$
} 


\section{국문초록}

\section{일반 노인의 유명인 이름대기 과제에서의 설단현상 특성}

김수정' $\cdot$ 최현주 ${ }^{2}$

1첨단인지학습센터, ${ }^{2}$ 나사렛대학교 언어치료학과

배경 및 목적: 보편적으로 연령이 증가함에 따라 설단현상의 빈도 역시 높아진다. 그러나 정상적인 노화과정에서 연령에 따른 설단현 상의 특성을 비교한 연구는 부족하다. 또한, 설단현상을 해결함에 있어 단서의 활용이 중요함에도 불구하고 이에 대한 연구는 제한적이 다. 본 연구에서는 일반 노인을 대상으로 연령집단에 따른 설단현상의 발생률과 반응유형 및 해결률을 알아보고 단서 제공에 따른 수 행력의 변화를 알아보는 것을 목적으로 하였다. 방법: 본 연구는 65-84세 일반 노인 96명을 대상으로 하였으며, 연령집단은 55-64세, 65-74세, 75-84세의 세 집단으로 구분하였다. 설단현상 과제로는 시대별, 범주별로 구성된 유명인 이름대기 30 문항을 사용하였다. 결 과: 첫째, 모든 연령집단에서 전체 인출 실패로 인한 설단율의 비율이 월등히 높았으며, 연령이 증가할수록 부분 인출 실패, 전체 인출 실패로 인한 설단율이 모두 증가하였다. 둘째, 유명인의 직업을 설명하는 설단반응 유형의 산출 비율이 모든 집단에서 가장 높게 나타 났다. 셋째, 모든 연령집단에서 음절 단서 제공 후 설단해결률이 자발적 설단해결률에 비해 높았으며, 자발적 설단해결률과음절단서 제 공 후 설단해결률 모두 연령이 증가할수록 낮아졌다. 논의 및 결론: 본 연구의 결과를 통해 연령집단에 따른 일반 노인의 설단현상의 특 성 차이 및 설단현상에서의 음운단서의 중요성을 알 수 있다.

핵심어: 노화, 유명인 이름대기, 설단현상, 음절단서

이 논문은 2019년 대한민국 교육부와 한국연구재단의 지원을 받아 수행된 연구임(NRF-2019S1A5A2A01035719).

\section{참고문헌}

강연욱 (2006). K-MMSE (Korean-Mini Mental State Examination)의 노인 규준 연구. 한국심리학회지, 25(2), 1-12.

기백석 (1996). 한국판 노인 우울 척도 단축형의 표준화 예비연구. 신경정신의학, 36(2), 298-307.

김미정 (2009). 알쯔하이머 치매환자의 중증도에 따른 유명인 이름대기 식별능력 연구. 이화여자학교 석사학위논문.

김정완, 김향희 (2009). 노년층 의사소통능력에 대한 문헌연구. 언어청각장애연구, 14(4), 495-513.

김정완, 황재호, 김수련, 김향희 (2013). 정상 노인의 연령에 따른 주의력 및 이름대기 능력의 차이. 언어치료연구, 22(3), 25-44.

김현진, 최현주 (2012). 알츠하이머병 환자의 양식(Modality)에 따른 이름대기 수행 능력의 비교. 대한치매학회지, 11(2), 53-58.

김향희, 허지회, 김덕용, 김정완 (2009). 실어증 선별검사(Screening Test for Aphasia Neurologic Communication Disorders: STAND). 서울: 학지사. 박지윤, 이고은, 이혜원 (2013). 한국어 음운 정보 산출에서 노화의 영향: 청년과 노인의 설단현상. 인지과학, 24(2), 111-132.

박현, 신혜정, 손명동 (2012). 노인들의 언어 문제와 언어 재활 인식에 관한 기초 조사. 언어치료연구, 21(4), 227-247.

오상아, 하지완 (2015). 노화와 경도인지장애가 사람이름 인출시 설단현상에 미치는 영향 대한치매학회지, 14(1), 39-47.

이고은, 이혜원 (2011). 철자 정보 산출에서 노화의 영향. 한국심리학회지: 인지 및 생물, 23(4), 549-564.

이예니, 최소영 (2016). 청년과 노인집단에서 어휘 특성에 따른 설단 현상 발생 및 해결 양상의 차이. Communication Sciences \& Disorders, 21(1), 139-150.

통계청 (2019). 2019 고령자 통계. 대전: 통계청.

\section{ORCID}

김수정(제1저자, 언어재활사 https://orcid.org/0000-0002-0315-5775); 최현주(교신저자, 교수 https://orcid.org/0000-0003-4654-3206) 